\title{
David Kozel
}

\section{Time Models in Myth and Music of the $20^{\text {th }}$ Century \\ Časovni modeli v mitih in glasbi 20. stoletja}

Prejeto: 1. oktober 2018

Sprejeto: 1. marec 2019

Ključne besede: mit, glasba, čas, vertikalni čas, ne-linearen čas, sodobna glasbe, neo-mitologizem

IZVLEČEK

Prispevek se ukvarja z vezjo med mitom in glasbo 20. stoletja. Mit je strukturni princip, ki vpliva na glasbo z re-mitologizacijo. Avtor analizira časovne modele $\mathrm{v}$ mitološkem mišljenju v primerjavi z novimi modeli časa v glasbi. Mit in glasba vsebujeta vertikalno in ne-linearno dimenzijo z določenimi manifestacijami.
Received: $1^{\text {st }}$ October 2018

Accepted: $1^{\text {st }}$ March 2019

Keywords: myth, music, time, vertical time, non-linear time, contemporary music, neomythologism

\section{ABSTRACT}

The study deals with the relationship between myth and music of the 20th century. Myth is a structuring principle affecting music by remythologisation. The author analyses time models in mythological thinking in confrontation with new models of time in music. Myth and music contain a vertical and non-linear dimension with specific manifestation.

\section{Mythologisation of Art}

$20^{\text {th }}$ century music uses new methods of work with time in music. The so far suppressed category of music structures has come to the foreground of composers' interest, in some cases becoming the dominant moment of music structuring. The new models of time in music, its structuring and articulation ${ }^{1}$, reflect the transformation of musical thinking from the past to the current century. The composition categories of

1 The term time articulation of music is taken from the work of the Czech music theorist Jaroslav Volek (1923-1989). See Jaroslav Volek. "K základním pojmoslovným distinkcím v oblasti časové artikulace hudby," in Čas v hudbě (Prague: SČSKU, 1984), 103-131. 
time and space in music can be explained as a consequence of development of style in music, effects on changed expression of the different art styles, ${ }^{2}$ the denial or development of the traditional procedures of music structuring, contact with and influence by non-European cultures ${ }^{3}$ in processes of globalisation and glocalisation ${ }^{4}$ etc. Can a suitable model for interpretation of the new models of time in music be found using the hermeneutic approach with an interdisciplinary combination of outputs of music theory, music aesthetics, anthropology, psychology or philosophy?" A possible inspiration can be found in mythic thinking, despite its difference from the rationalised thinking of the present-day man. Mythological thinking, narration and symbols continue to play an important role in the current development of art (music) culture. This is a transformed, intermediated and shifted functioning of the myth in terms of meaning and function. Identification of a potential mythological background of contemporary music phenomena permits finding their models (archetypes, symbols) in the myth and pointing out the ways of their transformation. The described approach to the transformations of time in music and mythological thinking is purely interpretative, based on the assumption of permanent effect of the myth on the present-day man and continuous revival of mythological structures and symbols in art. The results of this interpretation method are not mutually exclusive with the development of style features of music orientations and individual composer personalities. The interpreted relationship between myth and music structure is based on free relation, indirect analogy, symbolisation, metaphor, suggestion or semantic resonance. The process of mythologisation (remythologisation, neomythologism) runs consciously on the one hand, represented by aware and absolutely rational work with the mythological element and its inclusion into a music composition, but on the other hand, unconscious processes of intuition, personal and collective unconsciousness, etc., cannot be excluded. Terminology used describing these phenomena is then based on a particular theoretical starting point. ${ }^{6}$

The history of art culture includes a continuous process of demythologisation culminating in the period of Enlightenment of the 18th century or the positivist science of the 19th century. Art culture of the 20th century is characterised by a revival of interest in myths. In that period, mythologisation was perceived as a specific creative

2 Compare also development of non-figurative painting, abstract art, new methods of work with space and time, development of non-linear narration, etc.

3 New models of time in music for European music can be interpreted as a specific type of Orientalism in music. Comp. Małgorzata Grajter, ed., The Orient in Music - Music of the Orient (Newcastle upon Tyne: Cambridge Scholars Publishing, 2017).

4 See David Hebert and Mikolaj Rykowski, eds., Music Glocalization: Heritage and Innovation in a Digital Age (Newcatle upon Thyne: Cambridge Scholars Publishing, 2018).

5 Time as a philosophical category is a subject of research for example for Henri Bergson, Edmund Husserl, Martin Heidegger, Suzanne Langer, Maurice Merleau-Ponty, Gilles Deleuze and others, but also of classical and post-classical narratology. Interdisciplinary study of time was performed by Julius Thomas Fraser (1923-2010), whose theory of time is based on the assumption of hierarchy and conflict. Please note also the establishment of The International Society for the Study of Time (ISST) in 1966 and the published proceedings from their conferences. The following monograph is a substantial work in musicology: Jonathan D. Kramer, The Time of Music (New York and London: Schirmer Books, 1988). See also the special issue of the journal Indiana Theory Review (1996, vol. 17, no. 2), devoted to theoretical reflections of time. The theme of time in music is intensely analysed in phenomenology and its applications on music art. Compare for example Martina Stratilková, "Husserlian Tradition in the Conceptions of Musical Time," Acta Universitatis Palackianae Olomucensis. Facultas Philosophica. Philosophica-Aesthetica. Musicologica Olomucensia 10 (2009): 169-180.

6 Compare the different starting points and terminology of deep psychology, analytic psychology, (post)structuralism, postmodernist thinking (deconstruction), etc. 
art poetics turning to mythology at the thematic or structural level. The accompanying phenomenon is reinterpretation of the mythological symbols traditionally passed from generation to generation. Let me remind selectively of the effect of the mythological archetypes of Carl Gustav Jung on 20th century art, the effect of mythological forms on music and literature in Claude Lévi-Strauss, ideological use of mythological forms in different in content political, social or art messages in Roland Barthes, mythological archetypes of narration in literature according to Northrop Frye, or revival of myth in novel and novella works by 20th century writers according to Eleazar M. Meletinsky. ${ }^{7}$ When looking for potential effects of myth on music, a possible starting point may be the ideas of the diversified the Tartu-Moscow School of Semiotics, represented by works of Yuri Lotman (1922-1993), Boris A. Uspenski (b. 1927), Zara Minz (1927-1987), Vladimir Toporov (1928-2005), Vyacheslav Ivanov (1929-2017) and others. ${ }^{8}$ Lotman and the whole school viewed culture as a multilayer complex of sign relations, the semiosphere, a semiotic universe. An interdisciplinary approach affecting all possible cultural manifestations was the characteristic feature of their semiotic theory. The evident spread of mythic symbols across 20th century culture is interpreted as a qualitatively new characteristic of thinking. However, the relationship to mythological contents is conscious (even though the authors include the effect of intuition, imaginative processes, symbolisation), as a consequence of interpretation of the myth by the contemporary person, no longer primarily affected by the mythological thinking in its original form. The structural and content inspiration of art with myth, according to the representatives of the school, is a feature of external consciousness symbolism (non-mythological consciousness, a conscious interpretative approach to mythological contents in culture) in relation to the original myth. This methodological assumption is based on the fact that the mythic state of mind cannot be restored in the nonintermediated form any more. ${ }^{?}$

In the interpretative approach outlined above, myth became a structural principle, a model of part of art thinking. The mythological principles, in a transformed form, like in the case of literature and visual art, also entered music, while preserving the peculiar principles and rules of music expression. The structural effect of myth on music has been successfully studied by musicologists on several occasions. A good example may be the monograph by Eero Tarasti Myth and Music, based on semiotic theories and music narratology. ${ }^{10}$ Direct impact of neomythologism on 20 th century music is studied by Victoria Adamenko in Neo-Mythologism in Music, where she identifies certain fundamental mythological principles and symbols such as repetition, binary

7 See Carl Gustav Jung et al., Man and His Symbols (New York: Dell Pub., 1968); Claude Lévi-Strauss, The Raw and the Cooked (New York: Harper \& Row, 1969); Roland Barthes, Mythologies (Paris: Éditions du Seuil. Points, 1970); Northrop Frye, Anatomy Of Criticism: Four Essays (Princeton: Princeton University Press, 1957); Eleazar M. Meletinsky, The Poetics of Myth (New York: Routledge, 2000).

8 See, for example, Boris A. Uspenskij, Vyacheslav Ivanov, Vladimir N. Toporov, Alexandr Pjatigorskij and Juri M. Lotman, "Theses on the semiotic study of cultures (as applied to Slavic texts)," in: Jan van der Eng and Mojmír Grygar, eds., Structure of Texts and Semiotics of Culture (The Hague, Paris: Mouton, 1973), 1-28.

9 Compare also Juri M. Lotman, Universe of the Mind (London, New York: Tauris, 2001).

10 Eero Tarasti, Myth and Music: A Semiotic Approach to the Aesthetics of Myth in Music: Especially that of Wagner, Sibelius and Stravinsky (Helsinki: Suomen musiikkitieteellinen Seura, 1978). 
opposition, cosmology, numerical symbols, circle symbols, etc. ${ }^{11}$ Last but not least, there is the significant contribution of Byron Almén A Theory of Musical Narrative, implementing the narrative archetypes from literature (myth) according to N. Frye and James J. Liszka to the narrative theory of music. ${ }^{12}$

The traditional (meaning European classical) music, like the classical myth, is based on the linear principle. Both myth and music need the time dimension for their existence, articulated in a linear manner by a sequence of events running one after another. In terms of narration, myth is based on a linear orientation. The existing tradition of tonal music is also based on the principle of teleological orientation within the harmonic system and its rules. The transformation of musical thinking in the 20th century and its categories is generally linked to the breakdown of the tonal centre of composition and tonality (the tonal centre as a paradigm of musical thinking) as the dominant structuring principle. As a consequence of that, composers began to focus on the other components of music and their new structuring. The music of the 20 th century found new ways of relativisation of the traditional linear dimension of temporality. This gave birth to non-linear concepts of time in music, static music layers denying linearity and the teleological development of music composition. The vertical dimension of music time and space has come to the foreground of listeners' experience. This has led to employment of various composition means based on the principles of repetition, discontinuity, stasis (drones, stasis in music). But let me return to myth: can a vertical dimension, a non-linear organisation of time, be found in mythological thinking? If yes, then these mythological models might be used as the starting point for interpretation of the described transformations in musical thinking on the basis of wider relations and links to the tradition.

\section{Time Models in Mythological Thinking}

The original Greek word mythos demotes, inter alia, narration or the process of listening. Temporality of myth is given by the progress of narration in time as well as an inner, specific mythic time per se. The myth brings an experience of time different from ordinary life. Whereas the empirical (historic) time is linear and runs as a sequence of events, the time of mythic narration is outside this linearity. Understanding a myth is realised through insight (in the sense of viewing the truths of the myth), experience, living the symbolic meaning and sense of the mythic narration in ritual activities. The process outlined is characterised by continual or leap detachment from linear narration towards holistic experience, the synchronous dimension of the myth, the mythic timelessness without any link to the present. A myth can be understood as a means of detachment from linear time, although it is unable to get rid of this natural dimension completely. If you interpret the myth as a psychic image of mental activity of man, then it implicitly

11 Victoria Adamenko, Neo-Mythologism in Music: From Scriabin and Schoenberg to Schnittke and Crumb (Hillsdale, NY: Pendragon Press, 2007).

12 Byron Almén, $A$ Theory of Musical Narrative: Musical Meaning and Interpretation (Bloomington: Indiana University Press, 2008). 
symbolises models and experience of the time horizons of human existence. The multivalent meaning of the time models in myth is reflected, for example, by the Ancient Greek terms chaos and cosmos (the chaotic origin of the non-structured world and the introduction of order into phenomena and principles), as well as chronos (the linear, quantitative time) and kairos (the time of the well-timed moment, inner quality). The mythological and philosophical symbol of time in the Ancient Greece was the sphere - the perfect circular (spatial) constant static three-dimensional shape. In addition to the linear dimension of mythic narration mentioned above, another characteristic time model is the cycle - repetition of the mythic act of hierophany, creation and their presentation in periodic cycles. An event described by a myth (ritual) keeps repeating, thus returning us to the sacred origin. This leads to the distinction between profane and sacred time and space. In addition to the linear dimension of mythic narration there is also the linear concept of time, connected with the historic awareness of historic events. This is an example of the Jewish-Christian paradigm of thinking, entered by the linear time of narration, the historically particularised interventions of God in human history and redemption. The presentation of a mythic event by narration or by a ritual act, on the other hand, is a manifestation of the non-linear dimension of myth. The empirical profane time is stopped and replaced with the mythic timelessness of a sacral nature, in which the categories of the past - the present - the future do not exist. The summarising of the temporal dimension of the myth mentioned above will now be precised with particular theoretical reflections from the areas of religion studies, anthropology, philosophy and art studies.

Ernst Cassirer understands mythic thinking as a self-contained symbolic form. ${ }^{13}$ The subject of his research includes the three categories of the mythic world defined by Kant: space, time and number: "What we have found to be true of mythical space applies also to mythical time; - its form depends on the characteristic mythical-religious accentuation, the distribution of the accents of the sacred and profane." 14 The time category is related to the space category. Cassirer characterises historic time as a linear sequence of points allowing for ad finitum returns from the present to the past. In contrast to that, achievement of the mythic time (for example through a ritual) is a permanent state in which the connection of the present to the future and to the past is absent, as the mythic time forms an uncrossable (irreversible) barrier separating "the empirical present from the mythical origin". ${ }^{15}$ The mythic time paradigmatically separates us from the empirically experienced time with its causal and linear relations, denying it. The mythic conscience is typically described by Casirrer as "a timeless consciousness" or "primordial time", the state of duration without anchoring in time with a qualitative and emotional nature. ${ }^{16}$ Mythic time is characterised by particularity and quality. Casirrer also mentions the music element of the mythic consciousness, based on a rhythmisation of religious ritual activities of passage and initiation, cosmic stages, biological

13 Ernst Cassirer, The Philosophy of Symbolic Form. Volume Two: Mythical Thought, transl. by Ralph Manheim (New Have: Yale University Press, 1955).

14 Ibid., 118-119. For the issue of time in myth, see chapters "The Mythical Concept of Time" and "The Formation of Time in the Mythical and Religious Consciousness".

15 Ibid.,106.

16 Ibid.. 
actions: "Thus, time as a whole is divided by certain boundaries akin to musical bars. But at first its 'beats' are not measured or counted but immediately felt. Above all, man's religious activities show a rhythmic articulation of this sort." ${ }^{17}$

The time dimension of myth is etiological. The syncretic mythological narration describes the origin and functioning of the world in an original mythic time, which is different from the present and which can be returned to through the myth (ritualised action). In this respect, Meletinsky points out the principle of identity: "(...) the fundamental characteristic of myth consists in linking the essence of events and objects to their origins. In myth, to explain the structure of something means narrating the manner in which it was formed." 18 The specific "mytho-logic" that he mentions talks about the original cause, and the mythic time is characterised as "the proto-time (Urzeit), the time of origin", as it exists before the empirical time. ${ }^{19}$ Although mythic thinking can be characterised as cyclic from the temporal point of view, an important role is also played by the paradigmatic distinction between the empirical (profane) and mythic (sacral) time and space. According to Meletinsky, the mythic past is a sort of co-existing alternative reality at the synchronous level. ${ }^{20}$ This idea is important for our theme of mythic time. The myth narration proceeds in a linear manner within the empirical time, but the presentation of the myth leads to a denial of this time dimension into a non-linear time where the known temporal and spatial categories do not work and a significant role is played by timelessness and the synchronous aspect instead. In this context, Meletinsky notes that the linear concept of time described above applies to the dichotomy of the mythic and the empirical time. ${ }^{21}$ The cyclic oscillation of the two time paradigms permits a differentiation between the mythical past (creative past, origin of things) and the present (which, as a consequence of the non-creative repetition of cycles, can be understood as static in contrast to the mobile - creative - mythical past). ${ }^{22}$ The models of mythic time include the cyclic element (based on repetition), subordinated to the binary dimension of the present and the past time (repetition, stasis versus mobility, creativeness). ${ }^{23}$

The distinction between the sacred and the profane space and time from the viewpoint of comparative religion studies is described by Mircea Eliade. ${ }^{24}$ The non-homogeneity of the space for religious man, in his opinion, is manifested by a distinction of sacral places interfering with the profane world. The acts of religious events connect us to the mythic time at the points of contact between the sacred and the profane space. Repetition of these archetypal events ${ }^{25}$ endlessly repeats the creative actions of gods, revered

17 Ibid., 108. Cassirer's concept of myth was followed, inter alia, by Susanne Langer, for example in her The Philosophy in a New Key (1942). See for example William Schultz, Cassirer and Langer on Myth: An Introduction (New York and London: Routledge, 2000).

18 Meletinsky, Poetics of Myth, 159 .

19 Ibid..

20 Ibid., 161.

21 Ibid., 162

22 Ibid..

23 "In primitive societies, the cyclical conception of time is in any case subordinate to the view of time as two dimensions, the past and the present." Ibid..

24 Viz Mircea Eliade, Cosmos and History. The Myth of the Eternal Return (New York: Harper \& Brothers, 1959); Mircea Eliade, The Sacred and the Profane: The Nature of Religion (San Diego [Calif.]: Harcourt Brace Jovanovich, 1987).

25 Eliade uses the term archetype in the sense of a sacred model, prototype, paradigm. Compare to the meaning of archetype in the analytical psychology of C. G. Jung. Examples of the sacred space archetypes include axis mundi, archetypes of the heavenly space, the symbolism of the centre, etc. 
heroes and their deeds. Event archetypes are defined as models for repetition, imitation. "Their meaning, their value, are not connected with their crude psychical datum but with their property of reproducing a primordial act, of repeating a mythical example." ${ }^{26}$ Myths represent models of the sacred time. The Latin phrase in illo tempore ("in those days") points towards the time existing before the world we know, the time of gods, the original time of myth. Eliade sees the importance of axiology in the rendering of these models of time (repetitions of a sacred event versus the profane time). The profane time is understood as valueless, useless, mediocre. For the purpose of contact with gods, there is the periodic regeneration of the sacred time in contrast to the profane dimension of our existence. The cyclic time is non-progressive (it is regenerative but de facto static). The cyclic time can regenerate ad infinitum. This type of time is opposed by Eliade with the linear time of the Jewish religion and later of Christianity with their monotheism, whose eschatology is oriented towards the future (final regeneration of time). Following Eliade one can summarise as follows: while the mythic sacred time can be renewed in cycles, the historic profane time cannot be renewed.

The synchronous aspect of the myth and music has become one of the determining methodological procedures of structural anthropology of C. Lévi-Strauss. ${ }^{27}$ In this respect, let me mention the iconic quotation from his work The Raw and the Cooked: "Both [myth and music], indeed, are instruments of the obliteration of time ." 28 The diachronic dimension of myth is transformed into a synchronous time, a self-enclosing structure containing an understanding of the myth in its invariant basis (the invariant langue identified by the manifestations of the parole). ${ }^{29}$ According to Lévi-Strauss, the synchronous dimension of the myth is detemporalised on the basis of action of two grids of a bipolar approach to nature and culture: the physiological and the cultural dimension. ${ }^{30}$ Another methodological principle of understanding myth is myth reading, adopted from music, as a score in both the horizontal and vertical direction: "Were we to tell the myth, we would disregard the columns a read the rows from left to right and from top to bottom. But if we want to understand the myth, then we will have to disregard one half of the diachronic dimension (top to bottom) and read from left to right, column after column, each one being considered as a unit." 31 Rituals played an important role in the lives of the primitive peoples. According to Lévi-Strauss, the function of ritual is connected with the properties of savage thinking (la pensée sauvage) characterised by the mythic time as timelessness, enclosure from the historic time, the effort to eliminate the flow of historic time by presentation of the mythic time through ritual. ${ }^{32}$ Ritual acts through the mythic past, the periodic repetition of events is an entry of the synchronous dimension of time to the diachronic time flow. Lévi-Strauss further defines three types of rituals with regard to the maintenance (continuity) of the mythic

\footnotetext{
26 Eliade, Cosmos and History, 4.

27 See for example Pandora Hopkins, "The Homology of Music and Myth: Views of Lévi-Strauss on Musical Structure," Ethnomusicology 21, no. 2 (1977), 247-261.

28 Claude Lévi-Strauss, The Raw and the Cooked, Mythologiques, vol. 1 (Chicago: University of Chicago Press, 1983 ), 16.

29 These theses are documented by the structuralist analyses by Lévi-Strauss concerning the Oedipus myth or the music composition Bolero by Maurice Ravel.

30 Viz Ibid., 16-17.

31 Claude Lévi-Strauss, Structural Anthropology (New York: Basics Books, 1963), 214.

32 Claude Lévi-Strauss, The Savage Mind (London: Weidenfeld and Nicolson, 1966), 236, and others.
} 
time: the rites of control (periodicity of rituals and life, the synchronous aspect), the historical rites (bringing the mythic history to the present) and the mourning rites (preserving the continuity of the present and the past). ${ }^{33}$ The characteristics of time models in myth and rite by Lévi-Strauss is documented by the following quotation: "It can thus be seen that the function of the system of ritual is to overcome and integrate three oppositions: that of diachrony and synchrony; that of the periodic or non-periodic features which either may exhibit; and, finally, within diachrony, that of reversible and irreversible time (...)." 34

\section{Mythologisation of Time Models by Music}

The traditional idea of time in music in European artificial music is based on the principle of succession, movement and continuity of musical events, the logic of development of music expression, heading towards a certain target, i.e., the teleological and linear time models. Time in music understood in this way, in connection with tonality as the unifying, organising and hierarchic system, ${ }^{35}$ permits connections of music events within the past-present-future horizons. The music tectonics are traditionally characterised by the successive alternations of the climax and the anticlimax. ${ }^{36}$ The accompanying phenomenon of this method of composition is that the given moment in music can be filled with sense in the expected manner and orientation in the music structure can thus be found. The supporting point is the memory, permitting connection and explanation of what has already happened in the composition, what is derived from the past, and what is likely to follow according to the music logic of the music paradigm and the given style expression. In this sense, the time in music as an anthropological phenomenon can be studied theoretically not only with regard to properties of music structures but, above all, from the psychological and aesthetic points of view - how the given music structure acts during listening experience (what its effect and impact on experience is).

Twentieth century music features increasingly non-linear organisation of the music structures and non-teleological concepts of time in music. ${ }^{37}$ The music temporality is stopped by the composer, music becomes static, and the music stream continuity is disturbed with the aim to explore new ways of listening to and composing music. One can also say that these procedures disrupt the continuity and linearity of the traditional music time in favour of evoking mythological time models. The listening strategies of the traditional linear and teleological music composition are no longer sufficient for understanding of and orientation in the new music structures. Music events in

33 Ibid., 236-237.

34 Ibid., 237.

35 The above mentioned also applies to modal music composed in the traditional linear, teleological model of time in music.

36 Markéta Štefková, a Slovak theorist of music, speaks about the conditions of meaningful interpretative grasp of time progressions in music, the "inner unity of their progress in time", the process of development of tension, its culmination and relief, accompanying interpretation of the meaningful music content. Markéta Štefková, O hudobnom čase (Bratislava: The Institute of Musicology, Slovak Academy of Science, 2011), 31.

37 The non-teleological composition method was already used by Richard Wagner in some of his compositions (Tristan und Isolde, Der Ring des Nibelungen): his music is linear but not always teleological. It could continue without a clearly audible target of final accomplishment. Compare his concept of the endless melody. 
compositions are no longer confined to references to the past and the future in the given music structure, and the very moment of the heard music is not composed of coherent music elements and principles of the existing logic of musical thinking. As mentioned by London: "In music of the 20th century we find explorations of discontinuity, non-linearity, fragmentation and chaos." ${ }^{8}$ The non-linear temporality is a feature of music and the contemporary multimedia and intermedia art. The linear temporality, on the other hand, remains an important model of time in art, only losing its dominant role. On the other hand, we cannot claim that non-linear and non-teleological composing completely dominated in the 20th-century music. These originally mythological principles of mythological thinking found their use in the 20th-century music in varying degree across the stylistic and compositional focus of the music. Here it is a chosen approach to the interpretation: the mentioned composition procedures are characteristic of some authors to varying degrees (see examples below); similarly, some compositions do not always have to dominantly use the mentioned temporal models of the myth but can just significantly appear in certain parts. In the 20th-century music, mythological models appear contextually and together with them, the traditional (i.e. linear, teleological, dominating in the quantity) musical creation continues.

According to Jonathan D. Kramer ${ }^{39}$, time in music can be divided into two main principles of linearity and non-linearity. Linearity is based on development: "the temporal continuum [is] characterised by [the] principle of composition and of listening under which events are understood as outgrowths or consequences of earlier events." ${ }^{40}$ Unlike linearity, non-linearity is the opposite of development: "it is the determination of some characteristic(s) of music in accordance with implications that arise from principles or tendencies governing an entire piece or section." ${ }^{11}$ Kramer notes that the processes of continuity and discontinuity are not necessarily related to these two terms, since discontinuity can be found in both linear and non-linear music layers. With regard to the development of musical thinking, discontinuity of the music stream is a means of denial or disruption of linearity. ${ }^{42}$ There is a transitory space between linearity and non-linearity. Kramer defines the following five categories. The traditional time of European artificial music is the directional linear time. Non-directional linear time is based on the sequence of music events with the absence of a clear direction and target of the music stream flow. Multiple time (multiply-directed time) corresponds to a music composition with a linear orientation of music events in a sequence with a clear beginning and end but not in any specified sequence and deductible logic of further orientation. ${ }^{43}$ This music heads forward but can develop in multiple directions

38 Justin London, "Time," Grove Music Online, accessed September 19, 2018, http://www.oxfordmusiconline.com/.

39 This is primarily described in Kramer's monograph The Time of Music. Further, see for example Jonathan D. Kramer, "New Temporalities in Music," Critical Inquiry 7 (1981-2): 539-556; Jonathan D. Kramer, "Moment Form in Twentieth Century Music," The Musical Quarterly 64, no. 2(1978): 177-194; Jonathan D. Kramer, "Postmodern Concepts of Musical Time," Indiana Theory Review 17, no. 2 (1996): 21-61.

40 Kramer, The Time of Music, 453.

41 Ibid., 20.

42 Kramer refers to the impact of non-European music cultures, where non-linear time models are inherent, as well as the technological factor of the recording technology and manipulations with the sound and its layers. Kramer, New Temporalities in Music, 543.

43 Kramer refers in his already quoted works to Claude Debussy: String Quartet (1893) and Jeux (1913). Symphonies of Wind Instruments (1920) by Igor Stravinsky is for him an example of an expression of discontinuity and non-linear procedures in music. 
according to the logic of musical thinking. Its target can be at its beginning, depending on the organisation of the music events. Moment time in music is characterised by a series of isolated and particular music events with total importance - each moment of this form is all-inclusive. The beginning and the end of the composition is not clearly defined by a gesture. Finally, vertical time is music with the horizontal dimension absolutely suppressed. This is the equivalent of timelessness in music, music stasis, with no temporal relations between the individual music moments. The phrases of music ideas - the typical feature of linearity - are absent. This music is non-teleological, the listener cannot rely on the memory of the previous music development in anticipation of the future development. ${ }^{44}$ Another important finding presented by Kramer is that music often combines more of these time categories which manifest themselves in different scope and strength. Music compositions do not present any "pure" type of a particular music time model. All depends on the music structure hierarchisation and the way of listening to it. ${ }^{45}$

An important role in 20th century music was performed by non-linearity and nonteleological music composition. ${ }^{46}$ The radically new requirements for listening strategies opened new methods of music structuring and narrative forms of contemporary music. ${ }^{47}$ Coping with these demands is described in an uncompromising manner by Kramer as follows: "We become overloaded with unfulfilled expectations, and we face a choice: either give up expectation and enter the vertical time of the compositionwhere expectation, implication, cause, effect, antecedents, and consequents do not exist-or become bored." ${ }^{48}$ Mythologisation of time models in music is most closely connected with moment time (moment form) and vertical time, updating the verticality of the time of the myth and the ritual, the mythic stasis and timelessness. It needs to be remembered that there is no direct equivalence between the time models in mythic thinking and the time models in music, there is only the interpretation of the possible symbolic meaning of the properties of the mythological and the music structures in the context of myth revival in 20th century and present culture.

The composition Kontakte (1959-1960) by K. Stockhausen is explained by the composer in the following quotation; please note the terms referring to the vertical dimension of music (myth) and timelessness here: "This concentration on the present moment - on every present moment - can make a vertical cut, as it were, across horizontal

44 Kramer, New Temporalities in Music, 555.

45 The text of this study follows a systemic theoretical approach to the theme of interest. Particular examples of the individual types of music time in 20th century compositions are shown in the quoted literature references. See also Footnote 40. In the case of the non-directional linear time, these examples include compositions by Arnold Schoenberg, Erik Satie, Charles Ives, Alban Berg, Iannis Xenakis, Aaron Copland, Luciano Berio, and George Crumb. Multiple time is used in compositions of A. Schoenberg, Harrison Birtwistle. Moment time is terminologically connected with the achievement of Karlheinz Stockausen, as well as Anton Webern, Igor Stravinsky, and Olivier Messiaen. Vertical time can be found in compositions by C. Stockhausen, John Cage and Steve Reich.

46 Kramer refers to the terminology used in the work of Leonard B. Meyer, and defining the music of Stockhausen or Cage as "directionless, unkinetic", "anti-teleological". See Leonard B. Meyer, Music, the Arts, and Ideas: Patterns and Predictions in Twentieth-Century Culture (Chicago: University of Chicago Press, 1967), 72, 81. Quoted from Kramer, The Time of Music, 4.

47 Comp. Vincent Meelberg, New Sounds, New Stories: Narrativity in Contemporary Music (Leiden: Leiden University Press, 2006); Jann Pasler, "Narrative and Narrativity in Music," in Time and Mind: Interdisciplinary Issues. The Study of Time, vol. 6, Julius Thomas Fraser, ed. (Madison: International Universities Press, 1989), 232-257.

48 Kramer, New Temporalities in Music, 550. 
time perception, extending out to a timelessness I call eternity. This is not an eternity that begins at the end of time, but an eternity that is present in every moment." ${ }^{49}$ What are the means of creation of this music form? in the moment form, linearity is of no essence, pushed to the background by discontinuity, supported with the absence of defined beginnings or ends of composition sections. The composition sections are not interconnected by any linear logic, but what remains is the music continuum of the individual events (blocks, moments). ${ }^{50}$

Another Kramer's analytic example of the temporal form and temporality in music is the orchestral composition Chronochromie (Time-Colour) (1959-1960) by Olivier Messiaen where the moment temporality is intensively present. The composition is divided into seven parts: 1 Introduction, 2 Strophe I, 3 Antistrophe I, 4 Strophe II, 5 Antistrophe II, 6 Epôde, 7 Coda. However, this division is not functional absolutely; the individual parts are played in succession without divides. The composition is characterized by its emphasis on the colour quality of the chords, application of a compositional system of symmetric permutations and incorporation of birds singing into the musical structure, but as regards the pursued theme, it is also a specific work with music temporality. The complexity of the composition is indicated by application of all three compositional techniques in a systematic unity. Messiaen evokes the moment temporality by various means, most importantly probably by the discontinuity in the music stream, which separates the individual musical moments. Kramer points out that the individual moments in the composition are put side by side as individual units without transitory or connecting parts. The dissimilarity of the individual moments is supported by the complexity of musical textures, instrumental colours, and compositional techniques. There is also the role of different proportions of the individual parts and the related musical moments as well as the irregular representation of the moments and their lengths in the individual parts of the composition. ${ }^{51}$ Kramer identifies another means of creation of the moment temporality by Messiaen, which is avoiding the traditional climax in the composition that would evoke the drama or the narrative procedures. In this context, Kramer philosophically comments: „Of course the dramatic curve is peculiar to Western art; it is not a universal of mankind, as Eastern music readily demonstrates. $\|^{52}$ The final incorporation of the bird song by the composer differs from the existing musical tradition: the different musical textures negate the principles of musical cadence and structures based on phrases or tectonic finish of the music. ${ }^{53}$

The vertical time in music abandons the element of linearity in favour of non-linearity as the main constituting principle. The static character of the composition cannot be associated with the traditional narrative interpretation of music. Kramer notes: "The result is a single present stretched out into an enormous duration, a potentially infinite

49 Karlheinz Stockhausen, Texte I, trans. Seppo Heikinheimo. The Electronic Music of Karheinz Stockhausen (Helsinki, 1972), 120-121. Quoted according to Kramer, Moment Form in Twentieth Century Music, 179.

50 Kramer refers in his quoted works to next compositions: Olivier Messiaen: Chronochromie (1960) and Oiseaux exotiques (1955); Anton Webern: Symphony (1928), Witold Lutoslawski: String Quartet (1964); Frank Zappa: Lumpy Gravy (1967), etc.

51 Kramer, Moment Form in Twentieth Century Music, 190-191.

52 Ibid., 191.

53 Ibid., 191-192. 
'now' that nonetheless feels like an instant." ${ }^{4}$ The listener's leap to the vertical dimension of music brings about different listening strategies, compared by Kramer to viewing a statue in time, when the object can be seen from all sides, angles, in detail or as a whole, from different distances, or from outside the room... ${ }^{55}$ Good examples are represented by minimalist compositions (Steve Reich, Philip Glass, Le Monte Young), the semantically open compositions by John Cage, as well as the extensive compositions with the principle of contrast suppressed by Morton Feldman. ${ }^{56}$ Non-linearity is the structural composition technique of 20th century music. Non-linear procedures result from weakening or denial of the relations between music elements and events which are perceived as distinctive and self-sufficient in terms of content. The way of listening is not based on the traditional search for relations between the past - the present - the future but focuses on the current moment of the music structure. Non-linearity is achieved by disturbance of the continuity of music and its compositional material. Vickery ${ }^{57}$ identifies non-linear procedures in music on the basis of various levels of music structure properties: integration, contingency, compressibility and determinacy.

An example of musical minimalism ${ }^{58}$ that creates musical non-temporality and verticalises the musical temporality by application of specific musical means is Music for 18 Musicians (1974-1976) by Steve Reich. The variety of the instruments used in the piece includes pianos, marimbas, vibraphones, violins, cellos, $\mathrm{Bb}$ and bass clarinet as well as human voices. Reich's aesthetic credo emphasises gradualism of the musical process allowing the listeners not only to enjoy detail elements of the musical changes in their musical experience but also the sum of all musical elements in their entirety in the light of the overall form. The roughly one hour long piece examines various levels of texture, harmony and colour of the music through multi-dimensional musical processes. Music for 18 Musicians combines several mythological principles, which found their musical expression. The verticality of the musical temporality is conditioned by the creation of a musical stasis. The fundamental principle of the myth - repetition - is elevated here to the form-making principle. The music stream is in constant motion (regular pulsating move of the instruments in repetitive patterns); the music is void of a teleological direction. Despite the gradual nature of the musical processes, the listener has to assume a vertical approach due to the extreme length of the individual repetitions. The principle of repetition and the permanence of the musical motion also negate the listener's ability of dramaturgic reference of the music to the horizons of the past, present or anticipated musical events. In connection with compositions by Steve Reich and Frederic Rzewski, Kramer argues that the musical motion in these cases is gradual and constant; because of the absence of hierarchy in the structure of the individual phrases, the temporality is more vertical than linear. ${ }^{59}$ The lack of hierarchy in the musical structure of the composition can be explained by the psychological terms of foreground - background. Our

54 Kramer, New Temporalities in Music, 549.

55 Ibid., 551.

56 Kramer (see New Temporalities in Music) gives several analysed examples of vertical time in music: John Cage: Variations V (1965); Steve Reich: Come Out (1966), Frederic Rzewski: Les Moutons de Panurge (1969).

57 Lindsay Vickery, "The Evaluation of Nonlinear Musical Structures," in Sound Scripts: Proceedings of the 2009 Totally Huge New Music Conference, Vol. 3 (2011), 74-84.

58 Cf. e.g. Robert Fink, Repeating Ourselves: American Minimal Music as Cultural Practise (Berkley: University of California Press, 2005).

59 Kramer, New Temporalities in Music, 551-552. 
hearing focuses on musical features that emanate from the musical stream and attract our attention. The musical background is on the other hand perceived as the continuum from which significant elements emanate into the foreground. Reich applies this principle in the mentioned composition: the regular pulse of the music stream is non-hierarchical, but the exposed instruments and voices emanate from it into the foreground and again merge with the pulse of the music stream. In this case, the musical temporality is non-hierarchical. The composition is characterized by another mythological element: cyclicity. Reich explains in his comment on this composition that it is based on the cycle of eleven chords, which are played at the beginning and at the end ${ }^{60}$ The individual chords pass through repetitive pulses of all instruments and voices and are the musical content of the individual sections of the composition.

Moment time and vertical time can be linked to musical expression of the static impression of time by means of expression. The static effect is paradoxically encountered at first sight for example in minimalist music, i.e., music with a process-based structure. The listening experience of these compositions (especially the early and radical phase of American minimalism) does not accentuate structural hierarchy, the temporality is strongly vertical and focused on the present moment. Thanks to the length of the repeated model (pattern) and its shifts, our ability to listen only referentially to the previous or future development of the music layer is reduced. The music time created is static, vertical, formed by the continuous cyclical movements of the music. The key element of minimalism in music is mythic thinking in the form of cyclic repetition. The cyclic repetition of a music pattern evokes timelessness, stasis. Tarasti relativises the narrative limits of minimalist music, even calling it anti-narrative, as it is based on a series of the current "now" moments without any clear temporal articulation. ${ }^{61}$ Tarasti links the temporal segmentation in minimalist music with the thesis of Lévi-Strauss on the effect of music (and myth) as an instrument of stopping time: "Minimalist music rejects temporal segmentation and traditional functions of musical time: in this music one can no longer distinguish among beginning, end, introduction, or other temporal functions of music. Here music really has become a machine that stops time (...)." ${ }^{62}$ The principle of repetition is connected with the ritual aspect taken from the time models of non-European cultures, and the mythological symbol of the circle and the sphere. Interpreting the manifestations of the mythologem of the circle and mandala in 20th century music, Adamenko notes the issue of renaissance of circular notation, manifested not only by the structure and notation of music but also in certain architectural and acoustic requirements for live performance of this music. ${ }^{63}$ She analyses minimalist compositions by Terry Riley, Le Monte Young, Philip Glass, and the manifestations of the symbol of the circle in K. Stockhausen and George Crumb. Inspiring is also her interpretation of the phenomenology of time and space in the ideas of Gaston Bachelard (La Poétique de l'Espace, 1957), whose terms "phenomenology of roundness"

60 Steve Reich, "Musicfor 18 Musicians. Composer's Notes," accessed February 15, 2019, https://www.boosey.com/cr/music/SteveReich-Music-for-18-Musicians/548.

61 Eero Tarasti, A Theory of Musical Semiotics (Bloomington and Indianapolis: Indiana University Press, 1994 ), 285.

62 Ibid., 284.

63 See chapter 7 of Where Time Turns into Space: The Mythologem of a Circle in the monograph by Adamenko, Neo-Mythologism in Music. 
and "vertical time" are put in a direct relation with the moment form of K. Stockhausen, "suspended time" of G. Crumb, as well as the ritual dimension of minimalism in music: "Bachelard's vertical time comes to mind when comparing minimalist music to archaic ritual, through which its participants have experienced mythic time." ${ }^{64}$

Music exploration of vertical and non-linear narration is also represented by use of simultaneous layers of music and libretto in scenic music forms. ${ }^{65}$ As noted by Everett: "The decades of the 1970s and '80s bear witness to the most radical and avantgarde transformation of opera and theatre; nonlinear or anti-narrative orientations replaced linear, goal-directed forms of narrative." ${ }^{66}$ Various music areas use various means to accentuate the vertical, static dimension of music and myth. For example: Grabócz thinks about the relationships between archetypal structures, initiation rituals and manifestations of stasis in opera, where the central character is newly symbolised through an initiation ritual, not by the classical narrative description. ${ }^{67}$ The music means of expression of stasis include the principle of repetition, drones, static harmony, enumeration, and additive tectonic procedures. "Since Cage, Stravinsky, and Messiaen, we have known that the representation of an Indivisible Whole, devoid of duality (Cage) of ontological time as opposed to psychological time (Stravinsky), and of the desire to present ,the theological rainbow (Messiaen) tend to create a kind of 'zero' time, a circular of cyclic time juxtaposing or superimposing stasis and directionality." ${ }^{68}$ Further manifestations of stasis in music are represented by compositions by Olivier Messiaen. Koozin ${ }^{69}$ interprets stasis in the works of this composer as a metaphor of eternity. The means of evocation of music stasis in Messiaen are based on limited hierarchy of the rhythmic and melodic elements, use of isorhythmia, non-retrograde rhythms, modes with limited numbers of transpositions, generally means of liberation from the causal relations of the music structure and abandonment of linear temporality. The search for new dimensions of music time also takes place in electro-acoustic music, deflecting from the linear models of the music narrative with its specific use of acoustic material without traditional semantic references to the existing sound universe of music. Typical consequences of this aesthetic approach are responded to by Grabócz emphasising characteristics of current electro-acoustic music such as stasis, plurality, time suspension and time stopping: "This period is marked by a musical atmosphere of stasis, of oblivion, of unreasonableness and non-narrativity." ${ }^{70}$

64 Ibid., 239.

65 See, for example, the non-linear narratives and multiple temporalities in the opera by Philip Glass Einstein on the Beach (1976), with the independent coexistence of the music and the libretto; or the classical example of the post-modern deconstruction of the simultaneous layers of the myth about Orpheus in The Masks of Orpheus (1986) by Harrison Birtwistle (music) and Peter Zinovieff (libretto).

66 Yayoi Uno Everett, Reconfiguring Myth and Narrative in Contemporary Opera (Indianapolis: Indiana University Press, 2015$), 7$. Everett analyses operatic works by Osvaldo Golijov, Kaija Saariaho, John Adams, and Tan Dun as examples of revival of mythic structures by fragmentation, non-linear and anti-narrative procedures.

67 Márta Grabócz. "Archetypes of Initiation and Static Composition in Contemporary Opera." In Music and Narrative since 1900, edited by Michael L. Klein and Nicholas Reyland. Bloomington: Indiana University Press, 2013, 101-124. The analysed compositions include works by François-Bernard Mâche, Pascal Dusapin, and Gualtiero Dazzi.

68 Ibid., 107.

69 Timothy Koozin, "Spiritual-temporal imagery in music of Olivier Messiaen and Toru Takemitsu," Contemporary Music Review 7, no. 2 (1993): 185-202

70 Márta Grabócz, "Narrativity and Electroacoustic Music," in: Eero Tarasti, ed., Musical Signification: Essays in the Semiotic Theory and Analysis of Music (New York: Mouton de Gruyter, 1995), 544. 


\section{Conclusions}

Pearsall summarises the semantic theoretical approach of L. B. Meyer and J. Kramer to application of non-linearity in music in the hands of the music avant-garde, with the aim "to assimilate cyclical conceptions of time characteristic of many non-European cultures." 71 The analysis of time model types in mythic thinking mainly focused on the cyclic concept. This time model, connected in mythic thinking with the phases of gods, nature and man, is materialised by ritual activity, periodically presenting the mythic time. The consequence of application of mythic time as a different paradigm with its rules is a stopping of the flow of historic (empirical, linear) time. This results in a vertical leap to a different temporal and spatial dimension. Profane time is replaced with sacral time. Mythic time aims towards the vertical dimension of the world, connecting man with the transcendental space. The principles described are specifically represented in music by the "discovery" of the vertical dimension of music time, compositional means of time stopping, music stasis, and non-linear composition procedures of a non-teleological nature. All of that is governed by specific music style rules but the potential source of these time models lies in the myth. Consistent application of the cyclical concept of myth and ritual and their music extension (maximisation of the cyclic principle in music, music minimalism, the principles of discontinuity, moment forms) resulted in the penetration of timelessness and vertical time into music thinking. The implementation of mythic models of time in 20th century music is primarily supported by the structure or form of mythical thinking. Here we are confronted with myth as the structuring principle on an archetype basis whose invariant form is repeatedly filled with new content. ${ }^{72}$ Non-linear thinking and vertical time require new music listening strategies whose presence can certainly be explained by the effects of exotic cultures, music technological and reproduction capabilities, style development rules, effects of other art forms (...), ${ }^{73}$ but also manifestations of neomythologism as one of the possible ways of interpreting these phenomena. I hereby do not identify any direct link between mythic thinking and the different awareness of 20th century man and his music, but I find here a revival of mythological symbols in new contexts and contents. Mythological symbols and patterns cannot be projected on any arbitrary cultural expressions of the new time, just as exotic expressions of music cultures cannot be projected on European (EuroAmerican) music. Without prejudice to the generality of the foregoing, it remains

71 Edward Pearsall, "Anti-Teleological Art: Articulating Meaning through Silence," in: Almén Byron, ed., Approaches to Meaning of Music (Bloomington and Indianapolis: Indiana University Press, 2006), 41.

72 Compare the theory of archetypes by Carl Gustav Jung. In this case, there is a psychologising approach of activation of conscious as well as unconscious processes in art creation. Compare, for example, the term correla(c)tivity by Július Fujak, denoting multilevel perception. Július Fujak, Musical Correla(c)tivity: Notes on Unconventional Music Aesthetics (Nitra, Slovakia: University of Constantine the Philosopher, 2005).

73 Music minimalism is related to the more general minimalist principle in visual art (minimal art). Synthesizing, integrating, syncretic or multisensorily oriented art is a return to the syncretic perception of the world by mythological thinking. Hermeneutic principles of interpretation of the relationship between music and other arts in relation to intermediality and integration are studied by the Slovak theorist of music and aesthetics Slávka Kopčáková: Slávka Kopčáková, "K súvztažnosti a interpretácii hudby a iných umeleckých médií," in HUDBA A UMENIA. Vzájomné vztahy a prieniky v kontexte intermediality a integrácie. Studia Scientiae Artis I. Acta Facultatis Philosphicae Universitatis Prešoviensis, Slávka Kopčáková, ed. (Prešov: Faculty of Arts, Prešov University, 2011), 37-89. 
a crucial finding that myth reveals some universal principles manifested in various ways in the course of the history of culture and art, including music.

\section{Bibliography}

Adamenko, Victoria. Neo-Mythologism in Music: From Scriabin and Schoenberg to Schnittke and Crumb. Hillsdale, NY: Pendragon Press, 2007.

Almén, Byron. A Theory of Musical Narrative: Musical Meaning and Interpretation. Bloomington: Indiana University Press, 2008.

Barthes, Roland. Mythologies. Paris: Éditions du Seuil. Points, 1970.

Cassirer, Ernst. The Philosophy of Symbolic Form. Volume Two: Mythical Thought. Translated by Ralph Manheim. New Have: Yale University Press, 1955.

Eliade, Mircea. Cosmos and History. The Myth of the Eternal Return. New York: Harper \& Brothers, 1959.

Eliade, Mircea. The Sacred and the Profane: The Nature of Religion. San Diego [Calif.]: Harcourt Brace Jovanovich, 1987.

Everett, Yayoi Uno. Reconfiguring Myth and Narrative in Contemporary Opera. Indianapolis: Indiana University Press, 2015.

Fink, Robert. Repeating Ourselves: American Minimal Music as Cultural Practise. Berkley: University of California Press, 2005.

Frye, Northrop. Anatomy of Criticism: Four Essays. Princeton: Princeton University Press, 1957.

Fujak, Július. Musical Correla(c)tivity: Notes on Unconventional Music Aesthetics. Nitra, Slovakia: University of Constantine the Philosopher, 2005.

Grabócz, Márta. "Narrativity and Electroacoustic Music." In Eero Tarasti, ed.. Musical Signification: Essays in the Semiotic Theory and Analysis of Music. New York: Mouton de Gruyter, 1995, 535-540.

Grabócz, Márta. "Archetypes of Initiation and Static Composition in Contemporary Opera." In Music and Narrative since 1900, edited by Michael L. Klein and Nicholas Reyland. Bloomington: Indiana University Press, 2013, 101-124.

Grajter, Małgorzata, ed.. The Orient in Music - Music of the Orient. Newcastle upon Tyne: Cambridge Scholars Publishing, 2017.

Hebert, David and Rykowski, Mikolaj, eds.. Music Glocalization: Heritage and Innovation in a Digital Age. Newcatle upon Thyne: Cambridge Scholars Publishing, 2018.

Hopkins, Pandora. "The Homology of Music and Myth: Views of Lévi-Strauss on Musical Structure." Ethnomusicology 21, no. 2 (1977), 247-261.

Jung, Carl Gustav et al. Man and His Symbols. New York: Dell Pub., 1968.

Koozin, Timothy. "Spiritual-temporal imagery in music of Olivier Messiaen and Toru Takemitsu." Contemporary Music Review 7, no. 2 (1993): 185-202.

Kopčáková, Slávka. "K súvztažnosti a interpretácii hudby a iných umeleckých médií." In HUDBA A UMENIA. Vzájomné vztahy a prieniky v kontexte intermediality a integrácie. Studia Scientiae Artis I. Acta Facultatis Philosphicae Universitatis Prešoviensis. Slávka Kopčáková (ed.). Prešov: Filozofická fakulta PU v Prešove, 2011, 37-89. 
Kramer, Jonathan D. "Moment Form in Twentieth Century Music." The Musical Quarterly 64, no. 2 (1978): 177-194.

Kramer, Jonathan D. "New Temporalities in Music." Critical Inquiry 7 (1981-2): 539-556.

Kramer, Jonathan D. The Time of Music. New York and London: Schirmer Books, 1988.

Kramer, Jonathan D. "Postmodern Concepts of Musical Time." Indiana Theory Review 17, no. 2 (1996): 21-61.

Lévi-Strauss, Claude. Structural Anthropology. New York: Basics Books, 1963.

Lévi-Strauss, Claude. The Savage Mind. London: Weidenfeld and Nicolson, 1966.

Lévi-Strauss, Claude. The Raw and the Cooked. New York: Harper \& Row, 1969.

Lévi-Strauss, Claude. The Raw and the Cooked, Mythologiques, vol. 1. Chicago: University of Chicago Press, 1983.

London, Justin. "Time." Grove Music Online. Accessed September 19, 2018, http:// www.oxfordmusiconline.com/.

Lotman, Juri M. "Theses on the semiotic study of cultures (as applied to Slavic texts)." In: Eng, Jan van der and Grygar, Mojmír, eds.. Structure of Texts and Semiotics of Culture. The Hague, Paris: Mouton, 1973, 1-28.

Meelberg, Vincent. New Sounds, New Stories: Narrativity in Contemporary Music. Leiden: Leiden University Press, 2006.

Meletinsky, Eleazar M. The Poetics of Myth. New York: Routledge, 2000.

Pasler, Jann. "Narrative and Narrativity in Music." In Time and Mind: Interdisciplinary Issues. The Study of Time, vol. 6, Julius Thomas Fraser, ed.. Madison: International Universities Press, 1989, 232-257.

Pearsall, Edward. “Anti-Teleological Art: Articulating Meaning through Silence.” In Almén Byron, ed.. Approaches to Meaning of Music. Bloomington and Indianapolis: Indiana University Press, 2006, 41-61.

Reich, Steve. "Music for 18 Musicians. Composer's Notes." Accessed February 15, 2019, https://www.boosey.com/cr/music/Steve-Reich-Music-for-18-Musicians/548.

Schultz, William. Cassirer and Langer on Myth: An Introduction. New York and London: Routledge, 2000.

Stratilková, Martina. "Husserlian Tradition in the Conceptions of Musical Time." Acta Universitatis Palackianae Olomucensis. Facultas Philosophica. Philosophica - Aesthetica. Musicologica Olomucensia 10 (2009): 169-180.

Štefková, Markéta. O hudobnom čase. Bratislava: Ústav hudobnej vedy SAV, 2011.

Tarasti, Eero. Myth and Music: A Semiotic Approach to the Aesthetics of Myth in Music: Especially that of Wagner, Sibelius and Stravinsky. Helsinki: Suomen musiikkitieteellinen Seura, 1978.

Tarasti, Eero. A Theory of Musical Semiotics. Bloomington and Indianapolis: Indiana University Press, 1994.

Uspenskij, Boris A., Ivanov, Vyacheslav, Toporov, Vladimir N., Pjatigorskij, Alexandr and Lotman, Juri M. Universe of the Mind. London, New York: Tauris, 2001.

Vickery, Lindsay. "The Evaluation of Nonlinear Musical Structures." In Sound Scripts: Proceedings of the 2009 Totally Huge New Music Conference, Vol. 3 (2011), 74-84.

Volek, Jaroslav. "K základním pojmoslovným distinkcím v oblasti časové artikulace hudby.” In Čas v hudbě. Praha: SČSKU, 1984, 103-131. 


\section{POVZETEK}

Mit je razumljen kot simbol in strukturni princip tega, kako umetnost vpliva na ustvarjanje na zavedni in nezavedni ravni. Umetnost in glasba 20. stoletja sta zaznamovana s ponovnim zanimanjem za mite v različnih oblikah. Neo-mitologizem je postopek oživljanja in reinterpretiranja mitov $\mathrm{v}$ umetnostni sferi s pomočjo kulturne zavesti o mitoloških vsebinah. Muzikologija preučuje učinke mitov na glasbo, kot nam npr. prikazujejo dela Clauda Lévi-Straussa, Eera Tarastija, Byrona Alména ali Victorie Adamenko. Linearni teleološki model, povezan s tonalnostjo - kot glasbeno paradigmo -, je tradicionalni model časa v glasbi. Mitološki način mišljenja vsebuje več različnih tipov časa. Najpomembnejši med njimi je ciklični čas, a imamo tudi vertikalni čas mitološke brezčasnosti. Mitološki čas je sakralni čas in tako drugačen od profanega časa. Modele mitološkega časa so preučevali raziskovalci kot, denimo, Ernst Cassirer, Eleazar M. Meletinsky, Mircea Eliade ali Claude Lévi-Strauss. Refleksija o glasbi 20. stoletja je odkrila nove model glasbenega časa in prostora. V tem kontekstu ni pomembno zgolj, kako je glasba strukturirana, temveč tudi akustični vtis skladbe, strategija poslušanja in izkustvo. To vključuje uporabo nelinearnih tehnik skladanja - kot zanikanja teleološkega, linearnega modela. Analiza časa v glasbi temelji na delu Jonathana D. Kramerja, ki je razlikoval med usmerjenim linearnim časom, neusmerjenim linearnim časom, večkratnim časom, momentanim časom in vertikalnim časom. V študiji je poseben poudarek na principih momentane forme, minimalizma $\mathrm{v}$ glasbi in na principu ponavljanja, kakor tudi na načinih ustvarjanja glasbenih zastojev (stasis) in na vlogi ritualov v glasbi 20. stoletja. Maksimiranje originalnosti mitološkega principa ponavljanja vodi k ustvarjanju brezčasnosti v skladbah. Nadaljnje metode vzbujanja mitološkega časa vključujejo diskontinuiteto, nereferenčne glasbene strukture in poudarjanje vertikalnih komponent glasbe. Podobno kot mit je tudi glasba sposobna negirati linearni čas s poudarkom na vertikalnih dimenzijah in z zaustavljanjem ali ukinjanjem glasbene linearnosti. Metode glasbenega in mitološkega izražanja so različne v svojih manifestacijah, toda mitološko mišljenje vsebuje modele in predloge, ki so uporabljeni v novejših glasbenih kompozicijah kot tudi v sodobnih strategijah poslušanja glasbe. 